\title{
Preparation of Micron Sized Mesoporous Silica and its use to Immobilize $\beta$-galactosidase from Aspergillus Oryzae
}

\author{
Zhenzhen Liu, Kexin Yin, Jiao Yang, Lingyun Dong, Sufang Sun* \\ College of Chemistry \& Environmental Science, Hebei University, 180 East Wusi Road, Baoding, \\ China
}

\begin{abstract}
Under acidic conditions, monodisperse micron sized mesoporous silica which had an about $1.4 \mu \mathrm{m}$ diameter, was synthesized by hydrothermal method using F127 $\left(\mathrm{EO}_{106} \mathrm{PO}_{70} \mathrm{EO}_{106}\right)$ as template and tetraethoxysilane (TEOS) as silica source. The surface area and pore volume were determined by nitrogen adsorption method, and the diameter of the mesoporous silica was obtained by field-emission scanning electron microscopy. Then the mesoporous silica was used firstly as a carrier for the immobilization of $\beta$-galactosidase from aspergillus oryzae, under the optimum conditions, the enzyme activity and the activity yield were 355.29 $U / g$ and $63.11 \%$, separately. Meanwhile, the fundamental properties of the immobilized enzyme, such as the influences of temperature and $\mathrm{pH}$, were assayed and valuable results were obtained.
\end{abstract}

Keywords: Mesoporous silica, Enzyme immobilization, Hydrothermal method, F127, TEOS

\section{INTRODUCTION}

Since the discovery of M41S materials in 1992 [1, 2], the synthesis of mesoporous silica with controlled nanostructures and macroscopic morphologies has received great attention. For example, much attention has been paid to the synthesis of well-defined mesoporous silica spheres since spheres are very promising for applications in chromatography, catalysis, cosmetics, and photonic crystals [39]. It is noted that monodisperse mesoporous silica spheres had been prepared by various synthetic routes, however, there were only few reports on the solution synthesis of monodisperse mesoporous silica spheres with micrometer-sized diameters [10].

In our work, the micrometer-sized mesoporous silica spheres were synthesized by hydrothermal method. After being tested in spheres diameter, specific surface area and pore volume, the mesoporous silica obtained above were activated by glutaraldehyde and then used firstly to immob- ilize $\beta$ galactosidase from aspergillus oryzae. Under the optimum conditions, the enzyme activity and the activity yield were determined. Meanwhile, the basic properties of the immobilized enzyme including $\mathrm{pH}$ stability, thermal stability and the operational stability were also tested.

\section{Materials ANd Methods}

\subsection{Reagents and Apparatus}

Apparatus: Magnetic Hotplate-Stirrer with timer $\left(\mathrm{MS}-\mathrm{H}-\mathrm{Pro}^{\mathrm{T}}\right.$ ), Vacuum Desiccator (DZ-6020), Ultraviolet Visible Spectrophotometer (T6 New Century), Water Constant Temperature Oscillator (SHA-B), and Transmission Electron Microscope (Tecnai G2 F20 S-TWIN) were applied in our research.

Reagents: Triblock poly(ethylene oxide)-poly(propylene oxide)-poly(ethylene oxide) copolymer Pluronic F127 $\left(M_{\mathrm{r}}=12600, \mathrm{EO}_{106} \mathrm{PO}_{70} \mathrm{EO}_{106}\right.$, Sigma-Aldrich Co. Ltd.), $\beta$-galactosidase (From aspergillus oryzae, Sigma-Aldrich Co. Ltd.), O-nitrophenyl- $\beta$-D-galactopyranoside (ONPG, >99.0\%, Bio Basic Inc.), TEOS (98.0\%, Aladdin Inc.), Sodium Cyanoborohydride (95.0\%, Shanghai Macklin Biochemical Co. Ltd.), (3-Aminopropyl) triethoxysilane (99.0\%, Shanghai Macklin Biochemical Co Ltd.), other reagents used are all analytical.

\subsection{Synthesis of Micron Sized Mesoporous Silica}

Firstly, the micron mesoporous silica microspheres were synthesized by hydrothermal method. After $0.5000 \mathrm{~g}$ of triblock copolymer F127 and $1.2500 \mathrm{~g}$ of $\mathrm{KCl}$ were dissolved in $30.0 \mathrm{~mL}$ of $3.0 \mathrm{~mol} / \mathrm{L}$ $\mathrm{HCl}$ under magnetic stirring. After $30 \mathrm{~min}, 2.4 \mathrm{~mL}$ of TEOS was added at room temperature. After magnetic stirring for $24 \mathrm{~h}$, the mixture obtained was transferred into a Teflon-lined steel Parr 
autoclave and heated at $100{ }^{\circ} \mathrm{C}$ for $24 \mathrm{~h}$. The white precipitate was got by filtration, dried and calcined at $550{ }^{\circ} \mathrm{C}$ for $6 \mathrm{~h}$ to remove the templates.

Secondly, the amino-mesoporous silica was synthesized. $5.0000 \mathrm{~g}$ mesoporous silica was put into the solution mixed with $100.0 \mathrm{~mL}$ toluene and $7.5 \mathrm{~mL}$ aminopropyl triethoxysilane, the mixture was refluxed with constant stirring at $110{ }^{\circ} \mathrm{C}$ for $12 \mathrm{~h}$ under the protection of nitrogen. Then, amino mesoporous silica was obtained by filtration, washed with toluene and acetone thoroughly, and dried $12 \mathrm{~h}$ at $80^{\circ} \mathrm{C}$ vacuum, then put in a desiccator to be used in the next step.

Finally, with $2.0 \mathrm{~mL} 25 \%$ glutaraldehyde and $8.0 \mathrm{~mL}$ diethanolamine being mixed together and stirred $30 \mathrm{~min}$ at $20{ }^{\circ} \mathrm{C}, 1.0000 \mathrm{~g}$ amino mesoporous silica obtained above was added [11], the precipitate was obtained with constant stirring for $4 \mathrm{~h}$ at $30^{\circ} \mathrm{C}$, after being washed completely with distilled water, it was put into $0.1 \mathrm{~mol} / \mathrm{L} \mathrm{HCl}$ solution. The aldehyde mesoporous silica was obtained after 30 min with stirring. After being washed with distilled water and dried at $60{ }^{\circ} \mathrm{C}$, it was stored to be used next.

\subsection{Immobilization of $\beta$-galactosidase}

$0.0500 \mathrm{~g}$ of the activated carrier was put into the enzyme solution ( $\mathrm{pH} 5.0$, concentration: $4.0 \mathrm{mg} / \mathrm{mL}$, $0.5 \mathrm{~mL}$ ), and then the reaction was carried out in the Water Constant Temperature Oscillator at $35^{\circ} \mathrm{C}$ for $4 \mathrm{~h}$. After that, the immobilized enzyme was filtered and washed with distilled water to wash the excess of $\beta$-galactosidase.

\subsection{Activity Assays of $\beta$-galactosidase}

Free enzyme and immobilized enzyme were determined according to the references [12], using ONPG $(1.5 \mathrm{mg} / \mathrm{mL})$ as the substrate. For the free enzyme activity, the free enzyme $(0.1 \mathrm{~mL})$ was added to the phosphate buffer $(0.1 \mathrm{~mol} / \mathrm{L}, \mathrm{pH} 5.0,0.9 \mathrm{~mL})$. The reaction was started by adding ONPG $(1.5 \mathrm{mg} / \mathrm{mL}$, $0.2 \mathrm{~mL}$ ). After exactly $15 \mathrm{~min}$ of incubation at $55^{\circ} \mathrm{C}$, the reaction was stopped by adding of $\mathrm{Na}_{2} \mathrm{CO}_{3}$ solution $(1.0 \mathrm{~mol} / \mathrm{L}, 2.0 \mathrm{~mL})$, and the amount of ONPG was measured directly at $405 \mathrm{~nm}$. For the immobilized enzyme activity, the immobilized enzyme $(0.0500 \mathrm{~g})$ was soaked in of the phosphate buffer $(0.1 \mathrm{~mol} / \mathrm{L}, \mathrm{pH} 5.0,1.0 \mathrm{~mL})$. The reaction was carried out and analyzed as above. All activity measurement experiments were carried out three times. One unit (1U) of $\beta$-galactosidase activity was defined as the amount of enzyme that released $1 \mu \mathrm{mol}$ ONPG in 1 minute at $55^{\circ} \mathrm{C}$.

\subsection{Operational Stability}

The operational stability of the immobilized enzyme was determined according to the following procedures. Five copies of the immobilized enzyme $(0.0500 \mathrm{~g})$ was taken and soaked in phosphate buffer ( $\mathrm{pH} 5.0,1.5 \mathrm{~mL}$ ), respectively. After constant temperature in water bath at $55^{\circ} \mathrm{C}$ for $2 \mathrm{~min}$, ONPG $(1.5 \mathrm{mg} / \mathrm{mL}, 0.2 \mathrm{~mL})$ was added to the mixture, and then the reactive mixture was analyzed as above. Afterward, the solid was filtered and washed thoroughly with distilled water and the above experiment was repeated under the same conditions.

\section{RESUlT AND DISCUSSION}

\subsection{Discussion about the Mesoporous Silica Particles}

\subsubsection{Morphology of Mesoporous Silica Particles}

Surface structure of the silica particles were characterized by Scanning electron microscopy (SEM) and the result was illustrated in Fig.1. The photographs showed that the mesoporous silica particle had an about $1.4 \mu \mathrm{m}$ diameter and a rough porous surface structure, which would be very suitable for the immobilization of enzymes due to the increasing in the surface area.

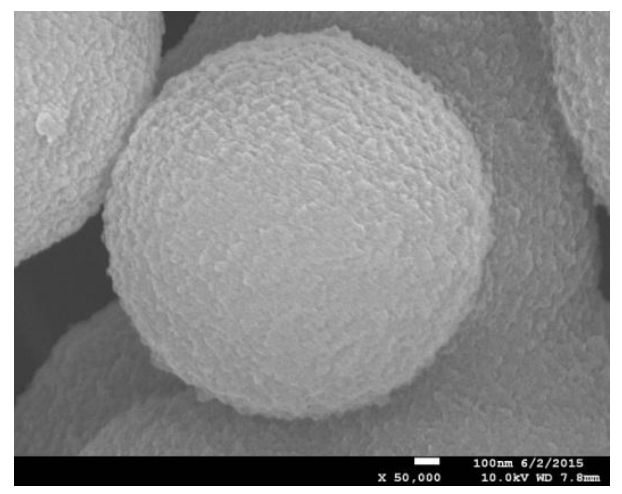

Fig1. SEM photograph of the mesoporous silica particle. 


\subsubsection{Surface Area and Pore Size of Mesoporous Silica Particle}

It was shown in Fig.2a that the nitrogen adsorption-desorption linear isotherms of the mesoporous silica obtained from Quantachrome Instruments version 3.01 was basically of type IV having H2 hysteresis loop [13], which confirmed the presence of disordered mesopores.

Meanwhile, the pore size distribution was also determined by density functional theory (DFT) method and the results were listed in Fig.2b, and it could be seen that a peek appeared when the pore width was about $6 \mathrm{~nm}$, which means the mainly existing pore size of the synthetic mesopores silica was about $6 \mathrm{~nm}$ in diameter.

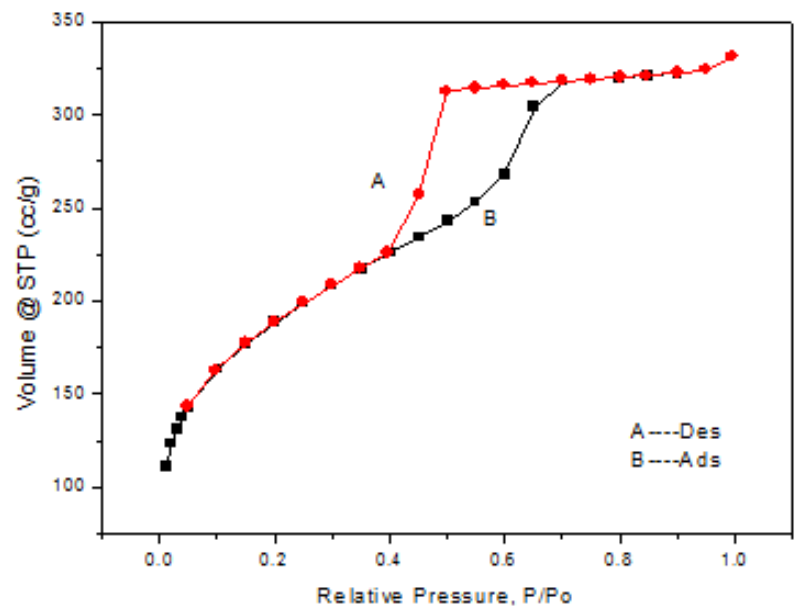

Fig2a. Nitrogen adsorption - desorption linear isotherms of mesoporous materials at $77 K$.

In addition, the pore size distribution was also determined by DFT method and the results were listed in Fig.2b, and it could be seen that a peek appeared when the pore width was about $6 \mathrm{~nm}$, which means the mainly existing pore size of the synthetic mesopores silica was about $6 \mathrm{~nm}$ in diameter.

Meanwhile, the pore size distribution was also determined by DFT method and the results were listed in Fig.2b, and it could be seen that a peek appeared when the pore width was about $6 \mathrm{~nm}$, which means the mainly existing pore size of the synthetic mesopores silica was about $6 \mathrm{~nm}$ in diameter.

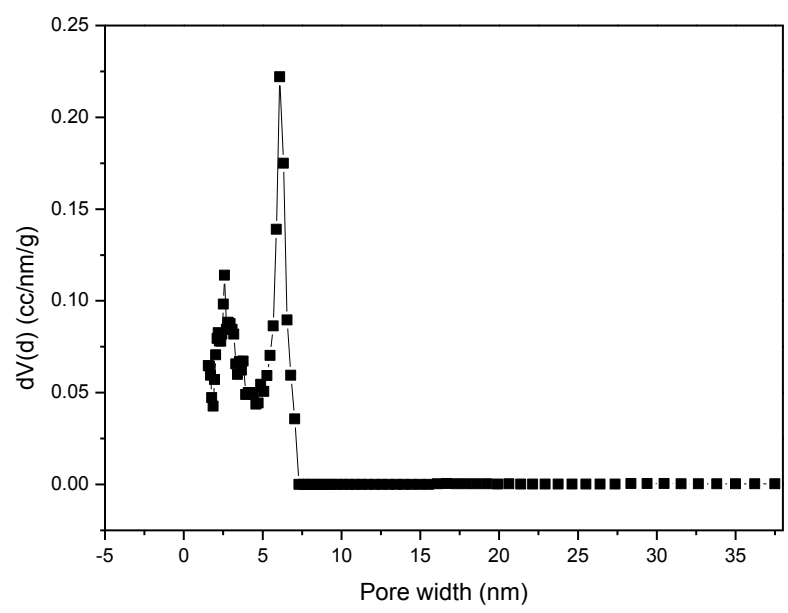

Fig2b. Pore size distribution of synthetic mesoporous materials by DFT method at $77 \mathrm{~K}$.

According to Multi-Point BET Plot Fig.2c, the BET surface area was calculated by Quantachrome Instruments Version 3.01 according to the following formula:

$$
\frac{1}{m\left(p_{0} / p-1\right)}=\frac{1}{m_{\text {total }} C}+\frac{C-1}{V_{m} C}\left(\frac{p}{p_{0}}\right)
$$

Therein, $m$ was the total mass of the adsorbed gas per gram carrier at adsorption equilibrium when the gas pressure was $p, m_{\text {total }}$ was the total mass of the adsorbed gas per gram carrier when its 
surface was fully covered by a single molecular layer, $p_{0}$ was the saturated vapor pressure of nitrogen at $77 \mathrm{~K}, C$ was adsorption coefficient.

According to Fig.2c and Equation (1), $m_{\text {total }}$ could be determined and its value was brought into the following formula,

$$
S_{s p}=6.023 \times 10^{23} \frac{m_{\text {total }}}{M} \delta
$$

Therein, $\delta$ was the cross-sectional area nitrogen and its value was $1.62 \times 10^{-19} \mathrm{~m}^{2}$ at $77 \mathrm{~K}$.

The specific surface area of the carrier $S_{s p}$ obtained according to Equation (2) was $646 \mathrm{~m}^{2} / \mathrm{g}$.

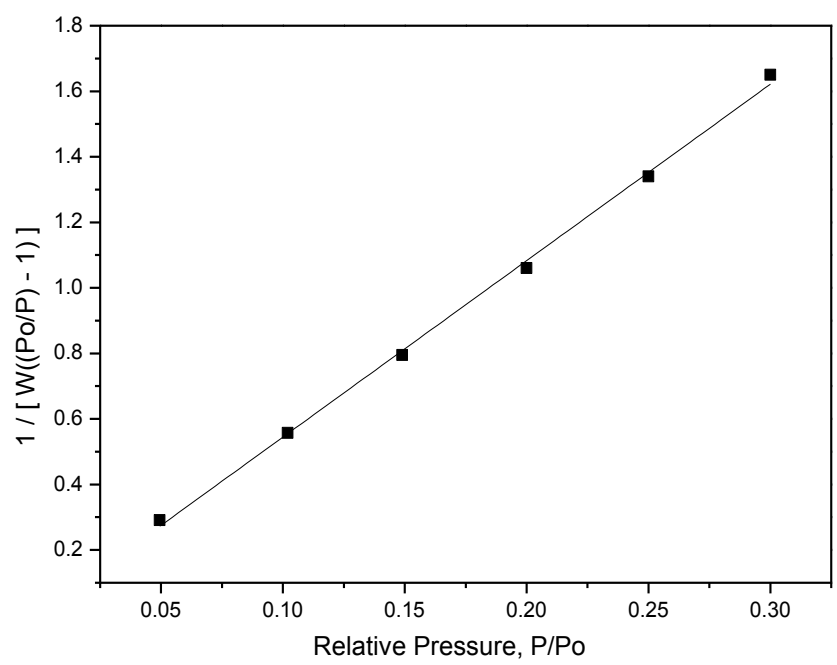

Fig2c. Multi-Point BET Plot of mesoporous materials at $77 \mathrm{~K}$.

\subsubsection{Fourier Transform Infrared Spectroscopy}

Two kinds of carriers including the pure mesoporous silica carrier (curve B) and that which had been used to immobilize enzyme (curve A) were analyzed by fourier transform infrared (FTIR), and the results were shown in Fig.3. It could be seen from Fig. 3 that a typical $1550 \mathrm{~cm}^{-1}$ observation peek was observed in the curve A, which directly showed that $\beta$-galactosidase had been fixed on the mesoporous particles.

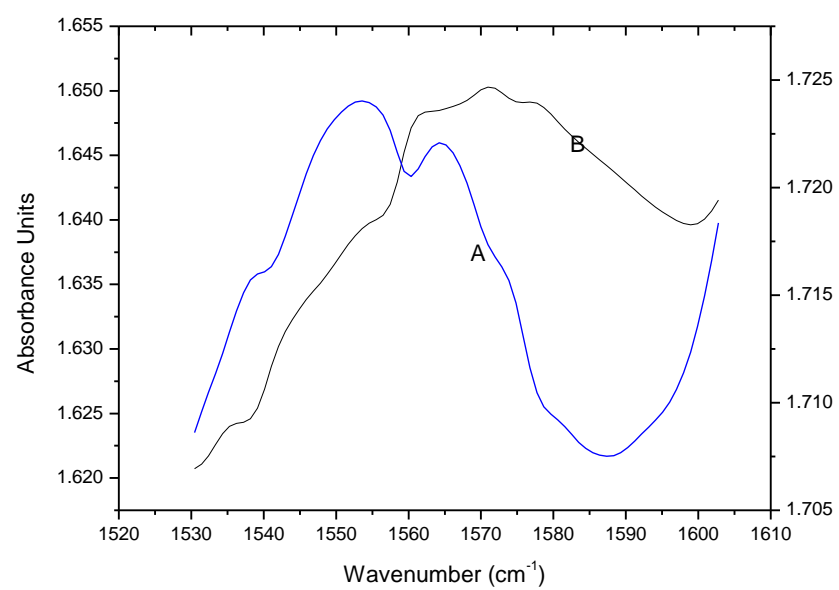

Fig3. FTIR spectra of as-prepared $\mathrm{SiO}_{2}$ spheres, and samples after immobilized enzyme. (A: the immobilized enzyme, $B$ : the pure silica carrier)

\subsection{Enzyme Activity and the Activity Yield}

Under the optimum conditions, $\beta$-galactosidase from aspergillus oryzae was immobilized on the micron sized mesoporous silica obtained, the enzyme activity and the activity yield determined were $355.29 \mu / \mathrm{g}$ dry carrier and $63.11 \%$ respectively, those data provided foundation for further study of the mesoporous carrier to immobilize enzyme. 


\subsection{Properties of the Immobilized $\beta$-galactosidase}

\subsubsection{Optimum Temperature and Thermostability}

The enzyme activities were determined with ONPG as substrate at various temperatures $\left(40-65^{\circ} \mathrm{C}\right)$ at $\mathrm{pH} 5.0$ for $15 \mathrm{~min}$, the results showed that the optimum temperature of free enzyme and the immobilized were both $55^{\circ} \mathrm{C}$.

The thermal stability of the two kinds of enzyme was measured respectively at $50{ }^{\circ} \mathrm{C}$ and $60{ }^{\circ} \mathrm{C}$. After $8 \mathrm{~h}$ at $50{ }^{\circ} \mathrm{C}$, the remaining activity of the free enzyme was $48.78 \%$ and the immobilized enzyme was $50.63 \%$. After $80 \mathrm{~min}$ at $60{ }^{\circ} \mathrm{C}$, the residual activity of the former was $17.43 \%$ and the latter was $20.15 \%$. So the residual activity of the immobilized enzyme was slightly better than the free enzyme, whether in the $50{ }^{\circ} \mathrm{C}$ or $60^{\circ} \mathrm{C}$.

\subsubsection{Optimum $\mathrm{pH}$ and $\mathrm{pH}$ Stability}

The enzyme activities were tested at $55{ }^{\circ} \mathrm{C}$ for $5 \mathrm{~min}$ in various $\mathrm{pH}$ ranging from 3.0 to 8.0 , the experimental data indicated that both enzymes attained their maximum activities in $\mathrm{pH}$ 6.0.

The $\mathrm{pH}$ stability of the enzymes was also determined by changing $\mathrm{pH}$ of the phosphate buffer. The results discovered that the free enzyme was very stable in the $\mathrm{pH}$ range of 3.0-8.0, while that of the immobilized enzyme were 3.0-7.0. When $\mathrm{pH}>7.0$, the activity of the latter decreased greatly, this might be caused by the characteristics of the silica carrier.

\subsection{Operational Stability}

The experiment was repeated 5 times by using the procedures mentioned above with the same immobilized enzyme at the same initial concentration of ONPG. The results got in Fig. 4 showed that there is no obvious decrease for activity of immobilized enzyme after being used five times, which means that almost no enzyme fell off from the mesoporous silica, so the immobilized enzyme had a good operational stability.

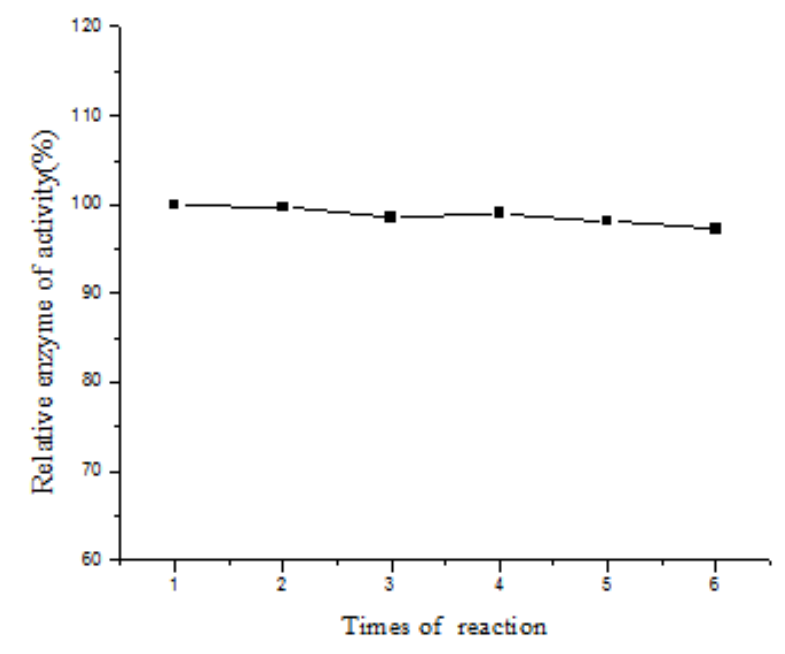

Fig4. Operation stability of immobilized $\beta$-galactosidase

\section{Conclusion}

In this paper, monodisperse micron sized mesoporous silica was synthesized by hydrothermal method with F127 $\left(\mathrm{EO}_{106} \mathrm{PO}_{70} \mathrm{EO}_{106}\right)$ as the template and tetraethoxysilane as silica source. Scanning electron microscopy (SEM) micrographs showed that the diameter of the silica material obtained was about $1.4 \mu \mathrm{m}$, and a rough porous surface structure was also found. Nitrogen adsorption-desorption isotherm revealed that disordered mesopores existed, surface area which was about $640 \mathrm{~m}^{2} / \mathrm{g}$ and a pore size which was about $6.0 \mathrm{~nm}$ were also determined. During the immobilization, FTIR analysis revealed directly that the enzyme had been fixed on the mesoporous particles. Under the optimum conditions, the enzyme activity and the activity yield determined were $355.29 \mathrm{U} / \mathrm{g}$ and $63.11 \%$ respectively.

Kinetic data determined from the immobilized enzyme was as follows: the optimal temperature and $\mathrm{pH}$ was $55^{\circ} \mathrm{C}$ and 5.0, separately, and the activity was very stable when $\mathrm{pH}$ ranged from 3.0 to 7.0 , the thermal stability of the immobilized was slightly better than that of the free enzyme. Operational 
stability showed that almost no enzyme fell off after being used five times again. Considering all the facts described above, the micron sized mesoporous silica, which has a great specific surface area, is valuable to immobilize enzyme and needs to be further studied.

\section{ACKNOWLEDGMENTS}

This work is supported by Program for the Top Young Innovative Talents of Higher Learning Institutions of Hebei Postdoctoral Science Foundation (B2015003006) and Natural Science Foundation of Baoding University (Grant No. 2014Z03)

\section{REFERENCES}

[1] Kresge C. T., Leonowicz M. E., Roth W. J., Vartuli J. C., Beck J. S., Ordered Mesoporous Molecular Sieves Synthesizd by a Liquid-Crystal Template Mechanism, Nature, 359(6397), 710712, (1992).

[2] Beck J. S., Vartuli J. C., Roth W. J., Leonowicz M. E., Kresge C. T., Schmitt K. D., Chu C.T-W., Olson D. H., Sheppard E. W., McCullen S. B., Higginsand J. B., Schlenker J. L., A New Family of Mesoporous Molecular Sieves Prepared with Liquid Crystal Templates, Journal of the American Chemical Society, 114(27), 10834-10843, (1992).

[3] Huo Q., Feng J., Schuth F., Stucky G. D., Preparation of Hard Mesoporous Silica Spheres, Chemistry of Materials, 9(1), 14-17, (1997).

[4] Grun M., Lauer I., Unger K. K., The Synthesis of Micrometer- and Submicrometer-Size Spheres of Ordered Mesoporous Oxide MCM-41**, Advanced Materials, 9(3), 254-257, (1997).

[5] Qi L., Ma J., Cheng H., Zhao Z., Micrometer-Sized Mesoporous Silica Spheres Grown under Static Conditions, Chemistry of Materials, 10(6), 1623-1626, (1998).

[6] Boissiere C., Kummel M., Persin M., Larbot A., Prouzet E., Spherical MSU-1 Mesoporous Silica Particles Tuned for HPLC, Advanced Functional Materials, 11(2), 129-135, (2001).

[7] Kosuge K., Singh P. S., Rapid Synthesis of Al-containing Mesoporous Silica Hard Spheres of 30$50 \mu \mathrm{m}$ Diameter. Chemistry of Materials, 13(8), 2476-2482, (2001).

[8] Kosuge K., Murakami T., Kikukawa N., Takemori M., Direct Synthesis of Porous Pure and Thiol-Functional Silica Spheres through the S+X-I+ Assembly Pathway, Chemistry of Materials, 15(16), 3184-3189, (2003).

[9] Kosuge K., Kikukawa N., Takemori M., One-Step Preparation of Porous Silica Spheres from Sodium Silicate Using Triblock Copolymer Templating, Chemistry of Materials, 16(21), 41844186, (2004).

[10] Yang L. M., Wang Y. J., Sun Y. W., Luo G. S., Dai Y. Y., Synthesis of Micrometer-Sized Hard Silica Spheres with Uniform Mesopore Size and Texyural Pores, Journal of Colloid and Interface Science, 299(2), 823-830, (2006).

[11] Tu W. X., Sun S. F, Nu S. L, Li X. Y., Immobilization of $\beta$-galactosidase from Cicer Arietinum (Gram Chicken Bean) and its Catalytic Actions, Food Chemistry, 64(4), 495-500, (1998).

[12] Ugelstad J., Ellingsen T., Berge A., Helgee O. B., "Process For Preparing Magnetic Polymer Particles," (1988).

[13] Liang J. X., Zhang X. K., Li X., Preparation and Characterization of Ordered Mesoporous $\mathrm{SiO}_{2}$ Under Certain Acidity, Journal of capital normal university, 32 (2014). 